\title{
Reforms of the Gabonese Education System: What challenges?
}

\author{
MBA Eyeghe Jean Paulin ${ }^{1}$ \\ ${ }^{1}$ Ministry of National Education of Gabon, Gabon \\ *Corresponding author: Ependja Towaka Antoine: aependja@gmail.com
}

\section{OPEN ACCESS}

Citation: Mba E. JP (2021) Reforms of Gabonese Education System: What challenges?. Open Science Journal 6(1)

Received: $2^{\text {nd }}$ November 2020

Accepted: $30^{\text {th }}$ November 2020

Published: 22 ${ }^{\text {nd }}$ March 2021

Copyright: (c) 2021 This is an open access article under the terms of the Creative Commons Attribution License, which permits unrestricted use, distribution, and reproduction in any medium, provided the original author and source are credited.

Funding: The author(s) received no specific funding for this work

Competing Interests: The author has declared that no competing interests exists.

\section{Abstract:}

In the field of education, the idea that an educational system can improve is not just an act of faith. Empirical research in social sciences and organizational management has shown that such improvement can only be achieved through reforms and their efficient implementation. However, studies have shown that, in a similar social context, certain approaches produce opposite effects. This article presents an overview of the reforms of the Gabonese education system from the 1960s to the present day. It has examined the main administrative acts that have framed the content of its reforms, highlighting significant advances in terms of material and social achievements. We noted that the Gabonese education system from the 1960s to the 1970 s increased the schooling of young people to more than $90 \%$. Twenty years later, the system was dysfunctional in terms of a shortage of qualified teachers, classrooms and quality of education. Added to this is the high rate of repetition and school failure. Thus, the manner in which education reforms are carried out in Gabon explains the delays noted.

Keywords: Reform, Education system, Education, Competency-based approach, Objective-based approach, Gabon

\section{Introduction}

In the field of education, the idea that an educational system can improve is not just an act of faith. Empirical research in social sciences and organizational management has shown that such improvement can only be achieved through reforms and their efficient implementation. However, this work emphasizes that, in a similar social context, certain approaches, educational institutions and systems produce contrary effects. 
This article presents an overview of the reforms of the Gabonese education system from the 1960s to the present day. It examines the main administrative acts that have framed the content of its reforms, highlighting the significant advances of the major reforms from 2009 to the present day in terms of material and social achievements.

The justification for this work is linked to the state of implementation of these reforms, some of which are still incomplete. Since we do not have the means to transform such a complex situation, we wondered about the current state of affairs. For this reason, in this text, we will show the situation yesterday and today, firstly by presenting the reforms of the 1960s to 1989 and then by presenting the reforms of the 1990s to the present day. Not having the means to transform a situation as complex as this one, we wonder like everyone else about a state of affairs that results in a kind of breathlessness leading to blockages in the implementation. To do this, we want to show in this text the situation of yesterday and today by setting the scene for the reforms of the 1960s to 1989, and then those of the 1990s to the present day. We want to enlighten the reformers on possible pitfalls to be avoided which most often benefit those who maintain the status quo at the origin of the situation of inertia that characterizes the Gabonese education system.

\section{Reform of the education system}

To begin, let's look at what is expected by reforming the education system.

A brief history brings us to the beginning of the 20th century with Émile Durkheim, for whom the educational system is a set of institutions that participate in the organization of school architecture, that is, the general course of study (cycles, streams, orientations, etc.).

In this light, we can agree with what some observers of the evolution of education systems say about the term reform. This is a major, radical change for the better. In this sense, the reform of an education system refers to changes in an organization such as the Ministry of National Education. The changes may be institutional, pedagogical and/or administrative, including laws, curricula, syllabi, evaluations, orientations and, to some extent, pedagogical practices. When a state embarks on a change, it must first and foremost define its objectives. Reforms are often initiated on the basis of a specific fact, for defined objectives and around general statements.

Gabon is no exception to this rule. In 1983 and 2010, the "Etats Généraux de l'Éducation, de la Recherche et de l'Adéquation Formation-Emploi" were organized as a prelude to major changes. But apart from these two major meetings, opportunities were found to reform the Gabonese education system. To this end, what about the implementation of the conclusions of these various meetings? Before reporting on the various reforms, it is first necessary to define a few concepts.

According to Savoie-Zajc (1993), implementing a decision or vision means making it concrete, putting it into practice or applying it to obtain results. For this author, implementing a reform in education implies moving from rhetoric to action, in other words, adopting an approach that makes it possible to obtain results. An education system is a heavy machine, with an abundance of infrastructure, programs, students, teachers, coaches, administrators, and other personnel. 
For Perrenoud (1999), reorientation in an education system can tend towards curriculum redesign, the adoption of new classroom practices or student evaluation, new technologies, as well as towards strengthening relations with families, developing school projects, local partnerships, or taking intercultural dimensions into account.

With regard to the reforms undertaken since 1964 at the Ministry of National Education of Gabon, we hypothesize that they were, for the most part, initiated by the Minister of Education and essentially concerned the structuring of the Gabonese school. Rarely was an in-depth diagnosis made. We believe that they were built on a diagnosis of opinions resulting from discussions with general directors, principals, pedagogical advisors and inspectors, teachers, students, field agents and social partners, who are difficult to identify as actors in a steering team or network for change.

In fact, it can be noted that the three phases of the change process, notably the diagnosis, deployment of the change mechanism and the steering process to maintain the course until the end of the process, have not been formalized in the majority of cases. According to Perrenoud, during the diagnosis phase, the leader identifies the problems of the Ministry of National Education, analyzes them, classifies them and formulates proposals, i.e., locates the problem by pointing out the programs, structures, classroom practices, teachers, pedagogical supervisors, the institutional framework and other Ministry personnel. In the same way, the diagnosis will allow the leader to classify the difficulties.

After the diagnostic phase comes the deployment phase which, according to Savoie-Zajc (1993), makes it possible to implement the established planning, ensuring that various commitments are respected and being aware that the motivation of agents must be continually maintained. From his point of view, communication plays an important role in this phase. It explains the purpose and methodology of the project, providing appropriate answers to agents' questions, identifying and learning about changes that have occurred. While we can agree that there has been a deployment during the reform undertaken at the Ministry of National Education since 2010, we still question the respect of the action plan, the taking into account of the specificity of the different actors and the level of difficulty that undermines the Gabonese educational system in the planning strategies chosen.

The piloting, which is the third phase of the implementation, requires the implementation of tools for permanent observation of the changes resulting from the project. For Autissier and Moutot (2003), it is built on the collection of indicators regarding knowledge of the project, the possibilities and the agents' willingness to act. In this sense, the analysis of these indicators enables the necessary adjustments to be made, by applying support systems (training, meetings), to keep the project on course. This is in line with our interpretation of Perrenoud's (1999) comments when he maintains that at the end of the process, the steering process proceeds to the perpetuation of the change, by ensuring the autonomy of the agents, by capitalising on the experience acquired in the transformation process. In view of the demonstrations by trade unionists, teachers and students three years after the start of the reform at the Ministry of National Education, one is entitled to wonder whether there have been any tools for observing and analyzing the change initiated.

Following Autissier and Moutot (2003), we maintain that the reforms initiated at the Ministry of National Education and Technical Education over the last thirty years have relied little on the levers we have just presented. Likewise, the 
consideration of some of these elements and the likely compliance with the adopted planning process has not brought the expected results.

Instead of collaborating in the conduct of reforms, the departments created to steer education have tended to compete with each other, preventing any consensus on the version of the curriculum and the legitimacy of the objects of the reform. The fact that the heads of these structures work in their own corners creates a situation of paralysis.

\section{State of play of the reforms from 1960 to 1989}

Freshly admitted to international sovereignty, the young Gabonese state in 1960 was confronted with the inadequacy of educational funding bequeathed by the French colonial administration. This constituted, for the Gabonese elites, an obstacle to achieving the objectives of the educational policy they wanted to establish. Among these reforms, we have selected four that seem to have marked the period from 1964 to 1984 .

\section{Reforms from 1960 to 1989}

These reforms have been torn between those nostalgic for the colonial past and those in favour of total independence.

Having kept several of the legacies of the colonial past, the new politicaladministrative elites committed themselves as early as 1964 to initiate the first reforms of the education system, based on a desire to gradually improve the quality of education (Nziengui Douckaga, 2008). For this author, this reform aimed to democratize education by promoting the education of all children, without distinction of social origin or gender, through compulsory schooling. It was also about gradually adjusting the education system to the real social, economic and cultural needs of the nation, he continues. The same author points out that the reform consisted in updating the curricula and teaching methods, specifying and defining the disciplines, developing textbooks and teaching aids better adapted to the Gabonese context and more formative.

Similarly, the reform also aimed to improve teacher training, status and pedagogical control (Nziengui Doukaga, 2008). However, this attempt did not live up to the expectations of those who wanted a total break with colonial supervision. This led the latter to promote the establishment of a legal framework to support the organization of the young education and training system. Hence the interest in adopting and promulgating a law organizing the young educational system.

Six years after its independence, Gabon will adopt a text setting out the general organization of education. It is law 16/66 of August 9, 1966 on the organization of education in Gabon.

This text is one of the very first legal frameworks regulating education in Gabon. It sets out the fundamental principles, notably the recognition of equal access to education for children and adults, free schooling for children aged 6 to 16 , equal opportunities between the sexes, the different levels of education, the criteria for awarding and monitoring scholarships, etc. The law also provides for the establishment of a system of financial aid for the education system. 
However, this law appears to be more an affirmation of Gabon's independence from France than a reform of the education system. But can it be said that this wish was shared by all the components of the political elite in place? This was certainly not the case. If until the mid-1980s, Gabon had covered universal schooling, the functioning and administration of education are in reference to the French education system.

In view of these hesitations, some attentive observers of the evolution of the education and training system in Gabon questioned themselves and felt the need to move the lines by planning two seminars for inspectors: the one in KoulaMoutou in 1975 and the one in Cap Esterias in 1979.

It should be noted in this regard that the seminars and colloquia have served, for more than a decade, as a mirror of the Gabonese education system and at the same time have been a powerful lever for certain reforms.

Within the general framework of a reform of the educational system, the importance and urgency of which was underlined by the second Extraordinary Congress of the Gabonese Democratic Party, the reform of primary education and, correlatively, the reform of the training of teachers and executives of the first degree has indeed taken on particular importance because of the significant increase in the number of students and the low output of primary education. On the basis of the above, the political decision-makers announced the holding of a major forum in 1983 which will be an opportunity to correct the shortcomings observed.

The Etats Généraux de l'Education et de la Formation held in Libreville from 17 to 23 December 1983 took up everything that had been emphasized during the inspectors' seminars. From a systemic perspective, an uncompromising diagnosis of the system of that time was made. To this end, the commissioners urgently recommend the conduct of a reform that takes into account the general aims of education, the reception structures, the training of teachers and the development of their careers.

Since material working conditions influence pedagogical action and student results, the commissioners insisted on the construction and equipment of new classrooms to eliminate overcrowding.

So what can we learn from the 1983 Estates General?

In view of the importance of the speeches, observers dreamed of in-depth changes in the education system.

In fact, it was more a matter of spontaneous announcements and expressions on education than of well-thought-out projects. This is illustrated by the sum of abandoned and unimplemented projects. This is the case with the question of recruitment and training. On this subject, we note that the École Normale Supérieure has continued to operate without an official frame of reference. The personnel deficit in all the educational professions has increased, and animation and pedagogical improvement have significantly disappeared from the missions of the actors in charge of supervision. Working conditions continued to deteriorate, creating a breeding ground for the major strikes that marked the political unrest of the 1990s.

In other words, the tensions between those nostalgic for the colonial past and the reformers who wanted to emancipate themselves plummeted the transformation of the educational system, sacrificing the few qualitative advances inherited from the colonial past that made the system proud between 1960 and 1990 . 


\section{Reforms from 1990 to 2009}

The last two decades in Gabon's recent history have been marked by sociopolitical upheavals that have not spared the education sector. It is within this sector that there has been the most turmoil, as the actors concerned have been the torchbearers of the changes achieved. Among other things, we will talk about some achievements in the careers of teachers, the construction of classrooms throughout the country and the introduction of the competency-based approach and its implementation at the primary level.

Gabon is not the only country that has been shaken by changes during the years 1990 to 2009. Socio-political changes have affected several Black African countries to varying degrees in the improvement of education systems. From Benin, Niger, Mali through Chad and Congo Brazzaville, as De Ketele (2020) argues, education systems have been under pressure from the rise of trade globalization, international developments, the performance of Asian education systems, supranational organizations and the market. In other words, according to this author, it is the tensions between the educational function of the school and those required by the evolution of society that will push the political authorities of French-speaking Black Africa to reform their education systems that are supposed to train the actors of tomorrow.

In the case of Gabon, Law 20/92 of March 8, 1993 establishing the special status of the education sector appears to be a founding text in the process of improving the salary conditions of lecturers. It determines the benefits, rights and specific prerogatives granted to education sector personnel.

During 2008 and 2009, following intense negotiations between the government and the social partners, the incentive bonus for the teaching profession (PIFE) was awarded to all teaching staff in the national education system. Even with these few gains, the teacher shortage is only worsening from pre-primary to secondary school and the contribution of these bonuses has not raised teachers' incomes relative to the standard of living in Gabon.

In addition to the social benefits obtained as a result of long strikes, the construction of several classrooms throughout the country is noteworthy. The majority of villages have been provided with classrooms but the growing demand from the big cities has not been absorbed.

And today the problem remains in Libreville, Franceville and Port-Gentil which are waiting for the construction of the buildings financed by the French Development Agency. It is in the light of these half-hearted results that we maintain that we are far from the mark because the social partners have not given up, as illustrated by the current strike of newly recruited teachers paid on pink slips.

But one of the great advances of this period was the curriculum reform at the primary level. This involved rewriting curricula in the form of skills development and assessment of student achievement.

Soungalo Ouédraogo (2010) argues that, for the past ten years or so, the international organization of the francophonie has been supporting the development of education in its member countries. It is in this context that such a reform has been carried out in Gabon.

Indeed, the issue of education for all has very quickly emerged as a quality education for all. Following the problem of transforming schools, Gabon could not avoid implementing such a goal. While the competency-based approach now appears to be a major change in the renewal of education policies and practices, 
it is clear that there is variability in its implementation, as Dieng et al. (2010) point out.

On this subject, we will not discuss the implementation of the competencybased approach in Gabon in the sense that Western promoters of this approach understand it. We note that the reform stopped at elementary school and did not cover pre-primary and secondary school. The language of instruction remains French. Teacher training, the development of textbooks and the implementation of teaching conditions for the Competency-Based Approach programs did not follow.

For Cros (2010), we also note a difficult break between the behavioural objectives approach and the competency-based approach insofar as the activities are presented in a behaviourist form. The results of national examinations show that the most successful students come from schools that do not practice the competency-based approach. The competency-based approach is a normative myth that is used to capture and divert public funds without being well understood and without a concern for social and cultural contextualization (Cros, 2010). In fact, the system retains all the artifices of the colonial past.

This leads some observers to say that it is a pale copy of the French system of the 1950s-1970s and that there is a lack of willingness on the part of the elites to keep their promises of change. This set of limits shows to the point the difficulty of the political-administrative elites to carry out a reform to the end. Besides, we can see it in their way of starting all over again during periods of renewal of the political classes.

\section{The great expectations of the years 2010}

The major reforms of the years 2010 come after the renewal of the politicaladministrative elites following the death of Omar BONGO Odimba on June 8, 2009 and the election of Ali BONGO Ondimba as head of state in September 2009.

In his campaign program, the new President announced reforms to articulate his social project to the system of education, training and research. In order to do so, he authorized the holding of the "Etats Généraux de l'Éducation de la Recherche de l'Adéquation-Formation-Emploi" from May 17 to 18, 2010. These reforms concern the generalization of pre-primary education, the reorganization of primary, general secondary, technical and vocational education.

Similarly, in 2007, the CEMAC Heads of State, following the Libreville Joint Declaration (February 2005), committed themselves to introducing the LicenceMaster-Doctorate (LMD) system in universities (Maganga, 2012). However, secondary education has continued to operate in the objectives or content approach, thus contributing to the disorganization between the different levels of education.

Considered as one of the first acts of concretization of the promises of the elected Head of State, the Estates General were like an acknowledgement of the frustrations experienced by social actors and administrative dysfunctions in the education system. This is why the conclusions will be more explicit about the fundamental reforms to be undertaken in the improvement of the education, training and research system. On this subject, the main recommendations concerned all levels of teaching, research and governance of the education sector. 


\section{Challenges to be met in the Gabonese education system}

In pre-primary and primary education, the desired innovations have focused on governance, curricula and classroom practices.

The targeted governance concerns the search for a ratio of 35 students per class by 2020 , quality school performance with a view to seeking social equity and equal opportunities among learners, the creation of specialized institutions to promote the schooling of disabled students, and the search for inclusion strategies through literacy and non-formal education.

Curricular innovations have aimed at the progressive introduction of national languages in schools, the assured mastery of oral and written communication in French and English, the motivation of a scientific, ecological, technological and citizen relevant awakening with basic prevocational skills.

Classroom practice points to a quality training of the teaching staff, the improvement of the pedagogical devices in order to bring help to students in difficulty. These various recommendations have been translated into legal provisions in the law 21/2011 of February 14, 2012 on the General Orientation of Education, Training and Research in its articles in Gabon.

With regard to general secondary education, changes in governance have concerned the abolition of the competitive entrance exam for the 6th grade, the search for a ratio of 35 students per class in all secondary schools, and the development of scientific, technical and vocational training at all levels, the reform of the baccalaureate through the introduction of early tests at the end of first grade, the creation of active student guidance systems from middle school onwards, the practice of equal opportunities for access to national exams, and the quality of recruitment and training of teaching staff.

As far as curricula are concerned, it is a question of renewing and harmonizing training programs and courses by introducing the competency-based approach by integrating the citizenship dimension, sustainable development, the current and mastered use of information and communication technologies, and a wide choice of the second foreign language from the sixth grade onwards. The objective is to reach a rate of $80 \%$ for the undergraduate certificate and the baccalaureate.

The reorganization, in the field of technical secondary education and vocational training, has mainly affected governance, infrastructure and quality human resources.

It is first to adapt technical education and vocational training to the demand of the productive sector through the creation of centers of excellence. This creation concerns the modernization of technical platforms and workshops with state-of-the-art equipment and the reinforcement of Gabonese teaching staff in scientific and technological subjects.

Then, the setting up of an integration fund and the strengthening of the public-private partnership by establishing a permanent exchange framework were envisaged. It was also proposed to strengthen the capacity of continuing education and its financing. Concerning training programs and courses, the reform focused on the writing of non-existent curricula, the implementation of pedagogical strategies developing the learner's empowerment.

In the end, the reform also considered supporting the professionalization of initial training, strengthening the alternating arrangements between training centers and the company, as well as controlling the quality of retraining. This is still pending. 
The question of the status of Education, Training and Research staff, which mainly covers governance, has focused on the specific status of Education, Training and Research sector staff.

Governance in education-training-research has advocated the establishment of a school map.

In the wake of these innovations, the integration of Information and Communication Technologies occupies a prominent place in the curricula of trainers and learners.

To improve the quality of evaluation in national examinations, the creation of a national office for examinations and competitions has been proposed. The generalization and diversification of partnerships with enterprises and organizations are strongly recommended to enable the establishment of a framework for the validation of professional achievements and experience.

All these concerns have led to the drafting of two bills, one dealing with the general orientation of education, training and research, the other focusing on the programming of investments in the education, training and research sector. Only the law on orientation has been adopted and promulgated.

Other application texts remain to be produced. However, the application of the texts fixing the modalities of preparation, organization and delivery of the undergraduate and baccalaureate certificates has not yielded the expected results. Instead, their application has led to a mess that has led to strong protests from unions, parents and students.

This state of affairs challenges all actors involved in educational issues, particularly managers of educational administrations and policies, and leads us to think, following Lessard (2009), that in public action in education, it is increasingly difficult to identify and maintain a policy and an overall vision over time that ensures the unity, coherence and consistency of everyone's efforts. For this author, education systems are more like ships suddenly caught in a storm, going from left to right, in search of a consensual and peaceful route that cannot be found for fear that a scoundrel wave will sweep away whole sections of them. From his point of view, the idea that the pilot is absent or does not know where he is going or that the system is ungovernable or that the environment is decidedly unpredictable and extreme, find many followers.

This could correspond to the situation in the education systems of Benin, Mali, Niger, Chad, Togo, Congo Brazzaville and Gabon, all members of the Conference of Ministers of Education of Countries Using French as a Common Language, which Cros (2010) analyzed, stressing the importance of ensuring the coexistence of top-down and bottom-up governance mechanisms, guaranteeing the continuity of responsibility and authority, in order to ensure the involvement of stakeholders throughout the reforms. We can see here some very distant cases of what Pons (2020) argued, namely that a successful educational reform is first and foremost a well-formalised reform, based on precise objectives, measures that are intelligible to the greatest number of people, but also elements of simple and effective language that are likely to win over conviction. For him, a successful educational reform is one that triggers partial public action with limited undesirable negative effects. It enables a group of significant actors to coordinate constructively and professionalize themselves to achieve common goals, regardless of whether the results actually achieved, studied in depth, live up to initial expectations or not. In this regard, one can agree with Blanquer (2020), when he notes that successful reform requires a pragmatic approach to the way public policy is conducted. Change must always be preceded by an awareness on the 
part of the actors, i.e., taking note of reality and sharing an observation before any reform.

\section{Conclusion}

This paper presented the situation of educational reforms since Gabon's accession to international sovereignty to date. In this portrait, we noted that, while in the 1960s and 1970s the Gabonese education system had succeeded in increasing the schooling of young people to over $90 \%$. Twenty years later, the system began to malfunction in terms of a deficit of qualified teachers, classrooms and quality of education provision. These led the highest authorities to initiate a series of reforms that did not produce the expected results as suggested by the high repetition and failure rates. To this end, we believe that if the reformers are struggling to implement the changes initiated, certainly there would be a problem in the administration of the education system. However, since education administration is linked to the adoption of acts, taking an interest in changes in a situation as complex as the one we have briefly described leads us to conclude that the way in which reforms are carried out within the ministerial department in charge of education and training in Gabon would explain the procrastination noted.

As a result, a deficit in organizational management. Through its conceptual and social anchoring, this study could contribute to a better understanding of the issues involved in the implementation of education reforms in Gabon. The interest of this overview is to make an inventory of the reforms that have been initiated. This could help reformers understand, as we pointed out in the introduction, what is at stake in the implementation of reforms. For us, it was not a question of explaining in detail the pitfalls in this area, still less of proposing solutions or remedies. This study is an overview that provides us with avenues for future research, particularly on the central issue of the organizational management deficit that seems to be emerging in this overview.

\section{References:}

Autissier, D. et Moutot, J.-M. (2003). La conduite du changement : changer de conduite. Paris : Édition : DUNOD.

Blanquer, J.-M. (2020). Les comparaisons internationales, la science et l'expérimentation au cœur des réformes en éducation, Revue internationale d'éducation de Sèvres, 83, p. 56-62.

Cros, F. (2010). Les réformes curriculaires par l'approche par les compétences en Afrique (p. 55-63), Actes des Assises sur les réformes curriculaires, Brazzaville, du 5 au 9 juillet.

De Ketele, J.-M. (2020). Réformer l'éducation. Introduction, Revue internationale d'éducation de Sèvres, 83, p. 12-22.

Dieng Sarr, A., Goza, N.A., Gbenou,P., Boupoupou, J.-C., Boutamba, B. et Randriambao, Y. (2010). Les pratiques de classes dans l'APC. La pédagogie de l'intégration au quotidien de la classe. (Sous la coordination de X.Roegiers). Bruxelles : De Beock Université.

Gouvernement Gabonais (1966). La loi N 16/66 portant organisation de l'enseignement au Gabon. Libreville.

Gouvernement Gabonais (1993). La loi N²0/92 fixant les statuts particuliers du secteur éducation. Libreville.

Gouvernement Gabonais (2013). Décret N 449/PR/MENESTFPRSCJS fixant les modalités de préparation d'organisation et de délivrance du Brevet d'Études du Premier Cycle. Libreville.

Gouvernement Gabonais (2013). Décret N 450/PR/MENESTFPRSCJS fixant les modalités de préparation d'organisation et de délivrance du Baccalauréat. Libreville. 
Lessard, C. (2009). La difficile légitimation des réformes curriculaires (p. 58-79). Dans V. Téhio et F. Cros (éds.), Politiques publiques en éducation : L'exemple des réformes curriculaires. Actes du séminaire final de l'étude sur les réformes curriculaires par l'approche par les compétences en Afrique. 10 et 12 juin.

Maganga, T. (2012). Explication du texte relatif à la Loi nº21/2011 du 14 février 2012 portant Orientation Générale de l'Éducation, de la Formation et de la Recherche », Colloque des directeurs d'école, 5 et 6 avril, Communication de Donguila, Ntoum.

Ministère de l'Éducation Nationale (2010). Les actes adoptés des États Généraux de l'Éducation de la Recherche de l'Adéquation Formation-Emploi. Multipress-Gabon.

Nziengui Doukaga (2008). Introduction de l'Histoire de l'Éducation au Gabon. Paris : Éditions Harmattan.

Perrenoud, Ph. (1999). Le pilotage négocié du changement dans les systèmes éducatifs, Faculté de psychologie et des sciences de l'éducation Université de Genève.

Pons, X. (2020). Qu'est-ce qu'une réformes éducative réussie? Une réflexion sociologique, Revue internationale d'éducation de Sèvres, 83 , p. 32-43

République gabonaise (1983). États Généraux de l'Éducation et de la Formation. Libreville : 17-23 décembre.

Savoie-Zajc, L (1993). Qu'en est-il de la triangulation? Là où la recherche qualitative interprétative se transforme en intervention sociale, dans l'Association pour la recherche qualitative, La recherche qualitative en éducation : réflexions sur ses fondements, ses méthodes et ses pratiques. Éditeurs : Marta Anadon et D.Côté-Thibault, hiver.

Soungalo Ouédraogo (2010). Économie de l'Éducation : Propédeutique, guide de recherche et d'autoformation. Paris : Éditions les Persée. 